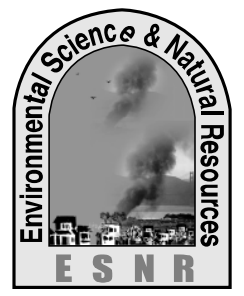

J. Environ. Sci. \& Natural Resources, 5(2): 251 - 261, 2012

ISSN 1999-7361

\title{
Coping Techniques of Local People to Flood and River Erosion in Char Areas of Bangladesh
}

\author{
M. S. Islam, T. Hasan, M. S. I. R. Chowdhury, M. H. Rahaman and T. R. Tusher \\ Department of Environmental Science and Resource Management, \\ Mawlana Bhashani Science and Technology University, Tangail-1902, Bangladesh
}

\begin{abstract}
This study is designed to explore the local people survival strategies and assesses variation in people's ability to cope with flood and riverbank erosion of two char land (Mid-channel Island) villages of Bangladesh. The data were collected by the application of social survey, key informant interview, focus group discussions and field observation. Most of the people of the char land villages were affected by both flood and river erosion. The result of the study showed that devastating river erosion occurred in Shushua char as compared with Degreer char in 2010 and people tried to adapt with adverse situation by their own techniques. People of both the chars were experienced flooding more than two months in the same year. Household's ability to adapt with flood and river erosion depends on people's socioeconomic and environmental conditions, such as education, income and occupation. Though, flood and river erosion cause the loss of lives and properties, people's indigenous coping techniques could significantly reduced their vulnerability without outside assistance. Effective early warning system, integrate local coping practice with modern technology and improve socioeconomic condition in a sustainable way are necessary to reduce the losses from flood and riverbank erosion.
\end{abstract}

Keywords: Bangladesh, Char land, Coping techniques, Flood, River erosion

\section{Introduction}

Char land is the Bengali term for Mid-channel Island that periodically emerges from the riverbed as a result of accretion (Elahi, 1991). The char lands of Bangladesh can be divided into five sub areas such as the Jamuna, the Ganges, The Padma, The Upper Meghna and the lower Meghna River. The old Brahmaputra and Tista also constitute some char land areas. The whole of the char land is unstable and prone to annual flooding. The char dwellers are some of the poorest and most vulnerable people particularly those who live on the Island/attached river chars although people living on the unprotected riverbanks experience similar difficulties (Roy et al., 2007). Floods are the main natural hazard faced by char dwellers and, in recent years, there were severe floods in 1987, 1988, and 1998 and more recently in 2004 and 2007. In 1987 and 1988, less than 10\% of the char area was above water during peak flood. By comparison, in the 'high normal flood' of 1991, about $50 \%$ of char land was flooded. Over $90 \%$ of houses were flooded in 1988 compared to about one third of the houses in 1991. Normal monsoon floods in the chars tend to be last for weeks rather than months, but floods can occur several times during the monsoon season (Tod, 2007).

The environmental disaster of riverbank erosion is a recurrent phenomenon in riverine Bangladesh which displaced one million people annually. The riverbank erosion displaces formulate and undertake corrective rather than preventive strategies for adapting to their hazardous riverine environment in their own ways. They usually tend to design multiple corrective measures, as none of those is adequate and effective for their purpose (Islam, 2009). From 1981-92 an estimated average of 36,220 people were displaced by erosion of mainland and attached chars every year. Island char erosion and accretion result more households being displacement Ninety percent (90\%) of the within-bank area had changed between char and water at least once during the period 1973-1992, with the consequence that the majority of char dwellers are likely to have been forced to move at least once during this period due to erosion (Kar and Hossain, 2001). Vulnerability comprises a set of attributes that circumstance turns into susceptibility to impacts (Lewis, 1999), and centers on the characteristics of a group or an individual in terms of their ability to predict, cope with, resist and recover from the shocks caused by natural hazards (Blaikie $e t$ al., 1994). This study, though, takes vulnerability mean the susceptibility of an individual to the negative impacts of flood and riverbank erosion hazards. Vulnerability depends on several factors like flood and erosion characteristics, physical infrastructure, geographic location, geomorphologic setting and people's cultural, political and socioeconomic condition.

Flood and riverbank erosion is common phenomena in different parts of Bangladesh. People in a flood and erosion affected locality adopt different measures to 
reduce the losses. Preventive measures are taken before the event while mitigative or corrective measures are taken during and after flood or riverbank erosion. Various structural (embankment, levee, polder etc) and non-structural (awareness raising, flood warning etc) measures have been taken for flood prevention and mitigation 12 . In recent years it become evident that structural methods are neither economically viable, requiring extensive financial investment, nor environmentally friendly (Wescoat and Jacobs, 1993). Moreover, the country's top-down approaches to planning have repeatedly failed to deliver timely and effective flood mitigation (Adnan, 1991) and no specific attention either by social scientist or by government on the land dislocation and population displacement due to riverbank erosion (Abrar and Azad, 2004; Zaman and Wiest, 1985). Therefore, now emphasize on local coping measures is increased and integrate those measures to mitigate flood and riverbank erosion. However, there is very limited and narrowly focused literature available on local people's traditional means of coping with floods 22, 23 and riverbank erosion. This study explores different preventive and mitigative or corrective measures taken by the people of two char land villages of Bangladesh to cope with the flood and riverbank erosion. In addition, it evaluates how different enabling attributes, such as education, income and occupation, affect the overall flood-coping strategy.

\section{Materials and Methods}

\section{Study area}

The study was conducted in two char land villages of Degreer char and Shushua char of Gobindashi and Arjuna union in Bhuapur upazila, Tangail district,
Bangladesh. Both villages are located north-western part of the Bhuapur upazila at a distance of 7.5 and 13 $\mathrm{Km}$ and are situated in the womb of the Jamuna River. In both villages, the majority of the households are either directly or indirectly dependent on agriculture for their livelihoods.

\section{Data collection and analyses}

Primary data related to flood and riverbank erosion were collected separately through key informant interviews, field observation, household questionnaire surveys (open and close ended), unstructured interviews, as well as via focus group discussion with household members from two study villages. Key informants were selected purposively while simple random sampling was used to identify households. A total of 100 households were selected from each study villages for data collection. Secondary data were collected from the Union Parishad office, Upazila Land Office, BWDB (Bangladesh Water Development Board). Data were collected from September, 2010 to February 2011 and analyzed by using SPSS V.12 and Microsoft Excel.

\section{Results and Discussions}

\section{Differences in flood-proneness in Degreer and Shushua char}

Both chars experience frequent flooding, but severity is higher in Shushua than in Degreer due to its low topographic feature. The Shushua char suffered high flooding in 2010 experienced average two to three months flooding while flood duration was two months in Degreer char. Thus, evidence of flood impacts shows that Shushua is more prone to flooding than Degreer. Table 1 represents different attributes pertaining to flood impacts in the study area.

Table 1. Impacts of flood in Degreer and Shushua char

\begin{tabular}{|c|c|c|}
\hline Flood impacts & Degreer char & Shushua char \\
\hline Availability of drinking water & $45 \%$ tube-wells safe & $22 \%$ tube-wells safe \\
\hline Loss of earnings & 7992.50 Tk./ household & 10215.75 Tk./ household \\
\hline Loss of assets & 12040.01 Tk./ household & 14650.08 Tk./ household \\
\hline Food security during flooding & $37 \%$ of households & $18 \%$ of households \\
\hline Access to safe drinking water & $48 \%$ of households & $32 \%$ of households \\
\hline Common diseases and conditions & Fever and diarrhea found in usual manner & $\begin{array}{l}\text { Catch cold, fever, diarrhea, chicken } \\
\text { pox and typhoid found in severely }\end{array}$ \\
\hline Sickness during floods & $1.4 \%$ of household & $1.6 \%$ of household \\
\hline Common flood shelter & Raised school field and roadside & Unsafe own house and roadside \\
\hline $\begin{array}{l}\text { Temporary migration during } \\
\text { flooding }\end{array}$ & $24 \%$ of households & $27 \%$ of households \\
\hline Impact on social mobility & $68 \%$ absent from school & $77 \%$ absent from school \\
\hline
\end{tabular}


Indigenous flood prevention and coping strategies People of both char villages practice their own adaptation techniques to cope with the flooding. People are used to relaying various indigenous strategies; the adoption of a particular set of techniques depends on people's socioeconomic circumstances and the characteristics of the flood. Our study found that, people use various preventive techniques includes the placing of barriers around the house, raising the platform of the house and preparation of Jagon (a float made out of water hyacinth and thatch). Other techniques like using muchan (an indigenous structure made out of bamboo or wood that is used as a platform) and Pataton (houses build with either bamboo or wooden ceiling in the upper part of the shelter where people live), reducing the number of meals and relying on inexpensive food, depending on relief, taking shelter along raise part like road, neighbor house, searching for alternative sources of income, selling assets, borrowing and selling land and other productive assets to mitigate the negative impacts of flood. The following subsections discusses overall preventive and mitigative strategies.

\section{Coping techniques to save human lives}

Previous works suggest that in flood-affected localities, coping starts with efforts to save people's valuable lives, such as raising a homestead before a flood. Our study found that, people of both chars used muchan frequently to rise up their homestead and save their lives. Survey also confirmed, preparation of jagon and its application during a sever flood are frequent in Shushua compare to Degree char. In Shushua vast amount of water hyacinth deposit during monsoon because of low topographic feature and people can easily collect those to prepare jagon. In case of worst situation people of both villages take shelter in relatively safe places like on embankment, roads or nearby chars. Though

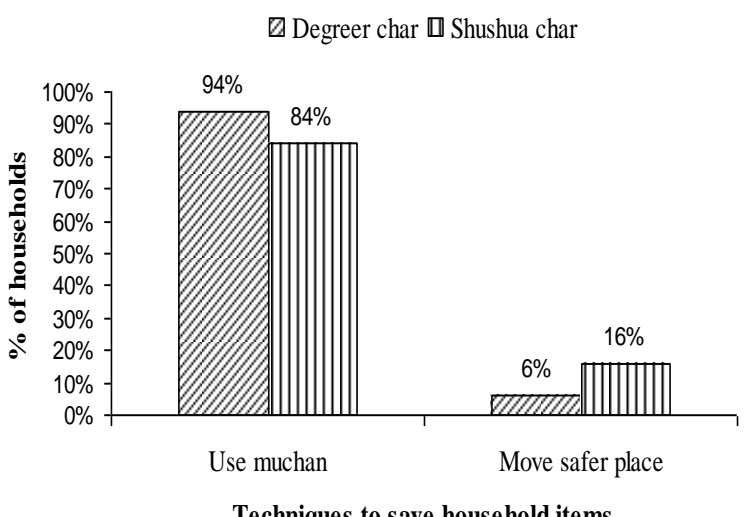

Techniques to save household items

Fig. 1. Coping techniques to save household items during floods strategies are common in both char but it may vary depending on the nature of flood, socioeconomic conditions and geographic location.

\section{Coping techniques to save household items}

Earlier study suggest that people try to rescue their assets (e.g. furniture and household products) initally by kepping them on a muchan or pataton besides to save valuable human lives. Our study also found that, most of the people of both villages used muchan to keep their household items during flood. Practice of this technique is relatively higher in Degreer char compare to the Shushua mainly because of its high topography. However, $6 \%$ people of Degreer and $16 \%$ of Shushua mentioned that they moved to safer places with their household items (Fig. 1) by boat or any other available means when the flood water rise.

\section{Coping techniques to save shelter}

Villagers in flood prone areas built their house on raised land so that water could not enter into the house during flood. In both villages, people use bamboo, corrugated iron sheet, thatch and wood for constructing their house which are easily to separate and transferable during flood as disaster. In addition, sometimes people make barriers by water hyacinth or place sandbags around the house to guard against the current. Use of water hyacinth barrier around the house is more frequent in Shushua than Degreer char because of its avialability. Raising homestead is another option for both villages to protect their shelter from flood. About 5 and 2\% respondent of Degreer and Shushua char said that they moved their shelter to a safer place during worst cases. Interstingly about 47 and $24 \%$ of Degreer and Shushua char people do not take any measure to protect their shelter during flood (Fig. 2). In Degreer this is mainly for high topography along with strong household structure but in Shushua, poor economic condition is prime reason for this condition.

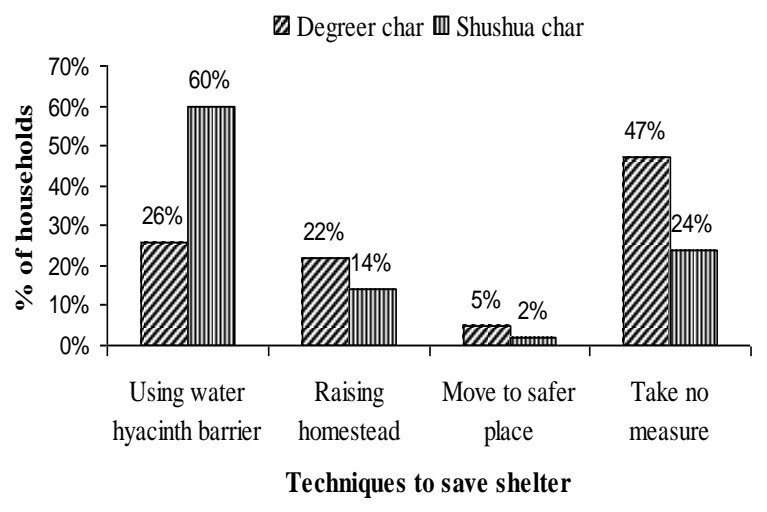

Fig. 2. Coping techniques of local people to save shelter 
Water purification techniques

Due to lack of awareness most of people of both villages do not take any measure to purify water for drinking during and immediately after flood. Only about $27 \%$ and $19 \%$ respondents of Degreer and Shushua char boil water for drinking pourpose. Few people of both villages use water purifying tablets and potassium alum for purification of drinking water. Different methods for water purification that are adopted by the both villages is presented in Fig. 3 .

\section{Local medicinal practices during and after flood}

Suffering from water-borne diseases and related conditions, such as cold, dysentery, diarrhea, fever and skin ailments, are common during and after a flood. It was found that a majority group of people in both villages (69\% in Degreer and 62\% in Shushua

\section{$\square$ Degreer char $\boxminus$ Shushua char}

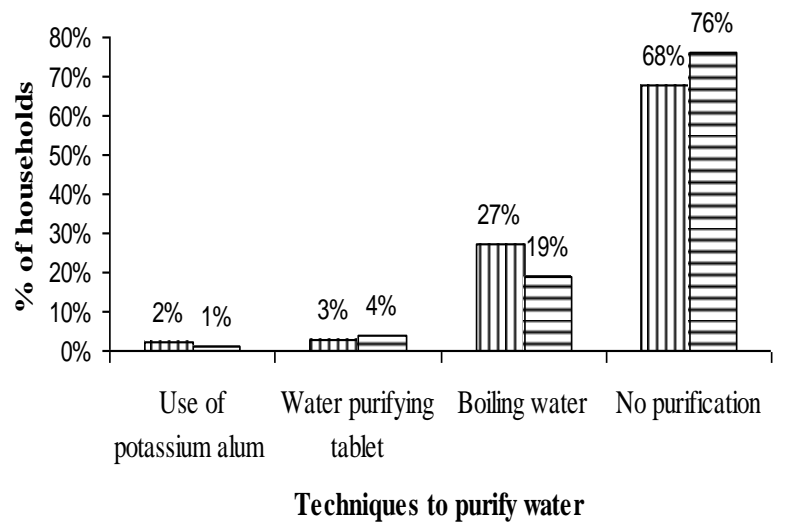

Fig. 3. Techniques to purified water during and after flood char) have taken medicine from local pharmacy without consultation a doctor and similar result was also found in previous study. Furthermore, people of both villages (5\% in Degreer and 4\% Shushua char) use herbal medicine on the basis of their indigenous knowledge to cure from diseases. The most commonly used in both villages are tulshi (Ocimum Sanctum), basak (Adhatoda Vasica), thankuni (Centella Asiatica), gando vadal (Gaultheria Fragrantissima), durba (Eragrostis Cynosuriodes) and pudina (Mentha Arvensis). Basak and tulshi are used to treat colds and fevers, whereas durba, gando vadal, pudina and thankuni are used for stomach problems such as diarrhea and dysentery. About $15 \%$ people of both villages do not take any measure during illness (Fig. 4).

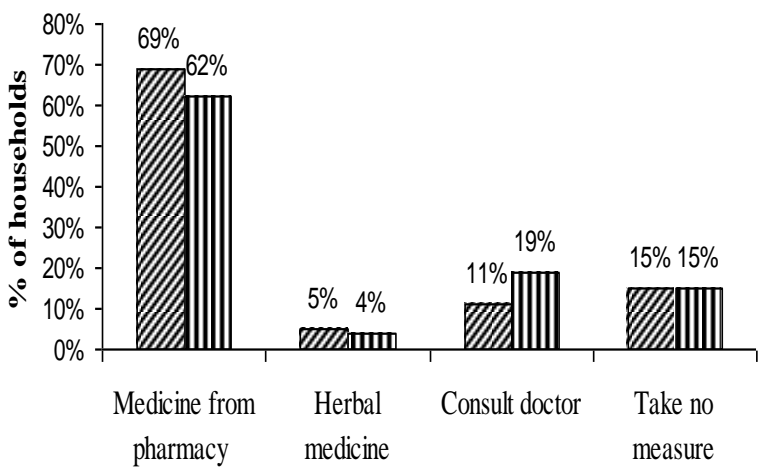

Taking measure during sickness

Fig. 4. Local medicinal practices during flood in

\section{Changes in eating behavior}

Scarcity of food during and after a flood is a common phenomenon in flood-affected areas. People generally try to cope with food shortage by taking several techniques like reduce the number of meal, depends on less expensive food (flattened rice, Jute leaf as a vegetable). Our study finds that, people of both villages reduce the number of per day meal and rely on less expensive food. About 75 and $95 \%$ of people in Degreer and Shushua char had decreased their number of meals and increased their dependency on inexpensive food. However condition is more sever in Shushua char because of low income level of the most people.

\section{Relation between copping techniques with different variables}

Earlier study suggested that, local techniques have a positive result to improving people's adaptability to a flood hazard but it depends on different complex factors like physical and socioeconomic variables. Therefore, the discussion of variations in the adoption techniques considers endogenous factors such as education, income and occupation and exogenous factors, such as external assistance, flood characteristics and riverbank erosion. Our study findings also suggest the same results and there is a practical relation between some variables with coping techniques taken by the affected people of both villages which discussed below.

\section{Relation between household's income levels with coping techniques}

Household's income level has a close link to coping strategies. Households with a higher income or with savings can readily help themselves in a flood event and hence are less vulnerable to flood impacts (Penning-Rowsell and Fordham, 1994). Table 2 represents the household's income level is associated with availability of food during and after a flood of 
both villages. The findings reveal that in both villages have negligible amount of higher level income group and food is available for them during and after flood. In case of upper middle class, about $50 \%$ of them from both chars had the storage of food during flooding while most of the low and lower middle income groups of both villages have inadequate food to tackle the situation. However, scarcity of food during flood is higher in Shushua char because of its high number of lower and lower middle class income group households. In addition eating behavior varies on the basis of income level. The study found that, except higher income group, all people of both villages reduce the number of meal and depends on less expensive food to cope with the flood. People of
Shushua practices these coping strategies more compared to Degreer char because of its high number of poor people. Interestingly, the behavior of higher groups is quite different. They prefer to reduce the number of daily meals than consume inexpensive food. The reason for this could be that this group is very aware of susceptibility to water-borne diseases during and after a flood 27.Selling of various assets to cope with flood generally depends on the income level of the affected people. Study showed that tendency to sell various productive and nonproductive assets during flood is higher in lower income group of both villages while compare to rest of the income group (Table 2).

Table 2. Relationship between household head's income level and food availability, changes in eating behavior and the selling of assets in Degreer and Shushua char

\begin{tabular}{|c|c|c|c|c|c|c|c|c|c|c|}
\hline \multirow{3}{*}{ Response } & \multicolumn{10}{|c|}{ Level of income (Tk.) of household head (HH) } \\
\hline & \multicolumn{2}{|c|}{ LL (0-2000) } & \multicolumn{2}{|c|}{ LM (2000-4000) } & \multicolumn{2}{|c|}{ UM (4000-6000) } & \multicolumn{2}{|c|}{ HL $(>6000)$} & \multicolumn{2}{|c|}{ Total } \\
\hline & HH & $\%$ & HH & $\%$ & HH & $\%$ & HH & $\%$ & HH & $\%$ \\
\hline \multicolumn{11}{|c|}{ Availability of food } \\
\hline Yes & 3 & 12 & 35 & 29.4 & 22 & 42.3 & 3 & 75 & 63 & 31.5 \\
\hline No & 22 & 88 & 84 & 70.6 & 30 & 57.7 & 1 & 25 & 137 & 68.5 \\
\hline Total & 25 & 100 & 119 & 100 & 52 & 100 & 4 & 100 & 200 & 100 \\
\hline \multicolumn{11}{|c|}{ Chi-square Test: Sig. value $=0.012$ with degree of freedom $=3$} \\
\hline \multicolumn{11}{|c|}{$\begin{array}{l}\text { Changes in eating behavior } \\
\text { a) Reduce number of meal }\end{array}$} \\
\hline & 12 & 26.1 & 33 & 33.5 & 25 & 45.5 & 5 & 83.3 & 75 & 37.5 \\
\hline \multicolumn{11}{|c|}{ b) Reduce meal and rely on less expensive food (both) } \\
\hline & 34 & 73.9 & 60 & 64.5 & 30 & 54.5 & 1 & 16.7 & 125 & 62.5 \\
\hline & 46 & 100 & 93 & 100 & 55 & 100 & 6 & 100 & 200 & 100 \\
\hline \multicolumn{11}{|c|}{ Chi-square Test: Sig. value $=0.022$ with degree of freedom $=3$} \\
\hline \multicolumn{11}{|c|}{ Selling of assets } \\
\hline Yes & 14 & 53.8 & 26 & 21.8 & 10 & 19.2 & 0 & 0 & 50 & 25 \\
\hline No & 12 & 46.2 & 93 & 78.2 & 42 & 80.8 & 3 & 100 & 150 & 75 \\
\hline Total & 26 & 100 & 119 & 100 & 52 & 100 & 3 & 100 & 200 & 100 \\
\hline
\end{tabular}

Note: $\mathrm{LL}=$ Low level, $\mathrm{LM}=$ Lower middle, $\mathrm{UM}=$ Upper middle, $\mathrm{HL}=$ Higher level

\section{Relation between level of education and capturing flood forecasting information}

Education level is very important in generating awareness of flood forecasting. Flood warnings can reduce the tangible and intangible damage experienced by flood victims (Parker and Tunstall, 1991). The findings shows that almost all household heads with higher secondary level education of both villages are able to capture flood forecasting information, whereas the numbers gradually decrease among household heads with secondary and primary school level education and among those who are illiterate. Hence, the higher the education level, the greater one's capacity to understand flood forecasting and to reduce one's vulnerability to flooding. Interestingly, literacy rate and different education level of the household heads of Degreer char is slightly higher compare to Shushua. Table 3 shows various education level and understanding of flood forecasting information of the people of both study villages. 
Table 3. Household head's (HH) education level and capacity to capture flood forecasting information in Degreer and Shushua char

\begin{tabular}{|c|c|c|c|c|c|c|c|c|c|c|}
\hline \multirow[t]{2}{*}{ Capture forecasting } & \multicolumn{2}{|c|}{ Illiterate } & \multicolumn{2}{|c|}{ Primary } & \multicolumn{2}{|c|}{ SSC } & \multicolumn{2}{|c|}{ HSC } & \multicolumn{2}{|c|}{ Total } \\
\hline & HH & $\%$ & HH & $\%$ & HH & $\%$ & HH & $\%$ & HH & $\%$ \\
\hline \multicolumn{11}{|l|}{ Degreer char } \\
\hline Yes & 13 & 28.9 & 12 & 37.5 & 14 & 70 & 3 & 100 & 42 & 42 \\
\hline No & 32 & 71.1 & 20 & 62.5 & 6 & 30 & 0 & 0 & 58 & 58 \\
\hline Total & 45 & 100 & 32 & 100 & 20 & 100 & 3 & 100 & 100 & 100 \\
\hline \multicolumn{11}{|c|}{ Chi-square Test: Sig. value $=0.003$ with degree of freedom $=3$} \\
\hline \multicolumn{11}{|l|}{ Shushua char } \\
\hline Yes & 21 & 32.3 & 8 & 40 & 10 & 83.3 & 3 & 100 & 43 & 42 \\
\hline No & 44 & 67.7 & 12 & 60 & 2 & 16.7 & 0 & 0 & 57 & 58 \\
\hline Total & 65 & 100 & 20 & 100 & 12 & 100 & 4 & 100 & 100 & 100 \\
\hline
\end{tabular}

Relation between occupation and availability of food The occupation of the household head is another important factor that influences the adoption of adaptation techniques. The study found that food was available to a household head of both villages engaged in business and it is gradually decreased in fisherman, laborers, and farmers (Table 4). The study also shows that taking loan during and after a flood is highest among laborers in both chars (Table 4). This is because the laboring class becomes jobless during long-lasting flooding and mostly loan from moneylenders, bank and nongovernmental organizations at a high rate of interest to meet food consumption requirements, increasing vulnerability due to a flood disaster. Scarcity of food and take lone during and immediately after flood is higher among the various occupation group of Shushua char compare to Degreer. However, our study shows that factors like higher income, higher education, alternative job during and immediately after flood, awareness etc can reduce the susceptibility of people during flood.

Table 4. Relationship between occupation of household heads $(\mathrm{HH})$ with availability of food and borrowing of money in Shushua and Degreer char

\begin{tabular}{|c|c|c|c|c|c|c|c|c|c|c|}
\hline & \multicolumn{2}{|c|}{ Farming } & \multicolumn{2}{|c|}{ Fisherman } & \multicolumn{2}{|c|}{ Laborers } & \multicolumn{2}{|c|}{ Businessman } & \multicolumn{2}{|c|}{ Total } \\
\hline & $\mathrm{HH}$ & $\%$ & $\mathrm{HH}$ & $\%$ & $\mathrm{HH}$ & $\%$ & $\mathrm{HH}$ & $\%$ & $\mathrm{HH}$ & $\%$ \\
\hline \multicolumn{11}{|c|}{ Degreer char } \\
\hline \multicolumn{11}{|c|}{ Availability of food } \\
\hline Yes & 20 & 38.5 & 2 & 28.6 & 5 & 31.3 & 17 & 68 & 44 & 44 \\
\hline No & 32 & 61.5 & 5 & 71.4 & 11 & 68.7 & 8 & 32 & 56 & 56 \\
\hline Total & 52 & 100 & 7 & 100 & 16 & 100 & 25 & 100 & 100 & 100 \\
\hline \multicolumn{11}{|c|}{ Chi-square Test: Sig. value $=0.042$ with degree of freedom $=3$} \\
\hline \multicolumn{11}{|c|}{ Loan to meet expenditure } \\
\hline Yes & 13 & 24.5 & 2 & 28.6 & 8 & 53.3 & 9 & 36 & 32 & 32 \\
\hline No & 40 & 75.5 & 5 & 71.4 & 7 & 46.7 & 16 & 64 & 68 & 68 \\
\hline Total & 53 & 100 & 7 & 100 & 15 & 100 & 25 & 100 & 100 & 100 \\
\hline \multicolumn{11}{|c|}{ Chi-square Test: Sig. value $=0.19$ with degree of freedom $=3$} \\
\hline \multicolumn{11}{|c|}{ Shushua $\operatorname{chr}$} \\
\hline \multicolumn{11}{|c|}{ Availability of food } \\
\hline Yes & 12 & 18 & 0 & 0 & 1 & 6.3 & 7 & 46.7 & 20 & 20 \\
\hline No & 55 & 82 & 2 & 100 & 15 & 93.7 & 8 & 53.3 & 80 & 80 \\
\hline Total & 67 & 100 & 2 & 100 & 16 & 100 & 15 & 100 & 100 & 100 \\
\hline \multicolumn{11}{|c|}{ Chi-square Test: Sig. value $=0.026$ with degree of freedom $=3$} \\
\hline \multicolumn{11}{|c|}{ Loan to meet expenditure } \\
\hline Yes & 29 & 44 & 0 & 0 & 8 & 53.3 & 5 & 27.8 & 42 & 42 \\
\hline No & 37 & 56 & 1 & 100 & 7 & 46.7 & 13 & 72.2 & 58 & 58 \\
\hline Total & 66 & 100 & 1 & 100 & 15 & 100 & 18 & 100 & 100 & 100 \\
\hline
\end{tabular}




\section{Riverbank erosion as environmental disaster}

People of Both Degreer and Shushua char were severely affected by the riverbank erosion in 2010. It causes losses of lives, property (land and crop), displaces people from their original homestead plot. We divided the erosion attack into very quick, quick, slow and very slow 4 . Our survey findings confirm that $92 \%$ displacees of Shushua char have experienced very quick erosion attack and rest of the displacees experienced quick erosion attack (Table 5). In case of Degreer char most of the displacees were affected by quick erosion attack while others have experienced very quick erosion followed by slow and very slow riverbank erosion. In addition, displacees also estimated the distance of their original homestead plot from the bank of Jamuna River during their last displacement. Majority of displacees (37\% of 200) from both villages established their houses at a distance up to 5 meters from the riverbank. Within this range all displaces experienced quick erosion attack and most of them did not get any proper opportunities for moving their livestock and other tangible properties and goods as well to a safer place from their original homestead plot. Only $13 \%$ displacees of both chars made their houses at a distance of greater than 15 meters (Table 5) and got the chance of moving to nearby safer places with their possessions.

Table 5. Nature of erosion-attack and distance of homestead from riverbank

\begin{tabular}{|c|c|c|c|c|c|c|}
\hline \multirow[t]{2}{*}{ Categories } & \multicolumn{2}{|c|}{ Degreer char } & \multicolumn{2}{|c|}{ Shushua char } & \multicolumn{2}{|c|}{ Both chars } \\
\hline & HH & $\%$ & HH & $\%$ & HH & $\%$ \\
\hline \multicolumn{7}{|l|}{ Nature of erosion attack } \\
\hline Very quick & 20 & 20 & 92 & 92 & 112 & 56 \\
\hline Quick & 62 & 62 & 8 & 8 & 70 & 35 \\
\hline Slow & 16 & 16 & 0 & 0 & 16 & 8 \\
\hline Very slow & 2 & 2 & 0 & 0 & 2 & 1 \\
\hline \multicolumn{7}{|l|}{ Distance (m) } \\
\hline$\leq 5$ & 38 & 38 & 36 & 36 & 74 & 37 \\
\hline$>5-\leq 10$ & 44 & 44 & 20 & 20 & 64 & 32 \\
\hline$>10-\leq 15$ & 16 & 16 & 20 & 20 & 36 & 18 \\
\hline$>15$ & 2 & 2 & 24 & 24 & 26 & 13 \\
\hline
\end{tabular}

\section{Adapting techniques of the displacees}

Displaces of Degreer and Shushua char undertake their adapting techniques at the individual level, as they are not responded by any organizational sources in this regard. Large scale technological control of structural engineering works are required to prevent riverbank erosion 4 which is absent in both chars. Displacees take some corrective measures like shift lives and properties, sell their housing materials and livestock to reduce the loss during and after riverbank erosion. The micro-level social, economic and political environment significantly influences the displacee's local adjustment strategies (Zaman, 1989).

\section{Loss reduction}

Several loss reduction techniques such as salvaging housing structure, sale livestock, cutting trees and standing crops are taken by the displacees of both villages to minimize from erosion attack. Our study finds that majority of the displacees of both villages (68\% in Degreer and 48\% in Shushua char) sell their livestock to reduce losses from erosion. Cutting standing crops is another option for the displacees of both chars (Fig. 5) though most of the crops are unusable. The loss reduction techniques of salvaging housing structure were practiced by the displacees of Degreer and Shushua char (29\% in Degreer and 19\% in Shushua char). This technique helped them to build a house on the nearby char or on the land owned by kin or neighbor after their displacement (Fig. 5). Few displacees of Degreer (20\%) and Shushua char (19\%) cut down their trees and saved it from riverbank erosion.

\section{Shift of lives and properties}

The shift of lives and properties from erosion threatened homestead to a safer place is one of the corrective strategies taken by the displacees of Degreer and Shushua char. It encompasses some measures- the shifting of family members, tangible properties and livestock from the erosion affected area to erosion free area. Earlier study suggested that people of erosion affected area shift their family member first than tangible properties and livestock 4, 33. A perusal of data explores that all the displacees $(100 \%)$ of both villages shifted their family members from their affected homestead plots to the 
embankment, roads, nearby char land, relative's shed, neighbor's land etc and to other villages as well (Table 6). The loss reduction strategies of moving tangible properties and livestock accounted for $70 \%$ and $84 \%$ respectively of both chars during erosion.

$\square$ Degreer char $\square$ Shushua char

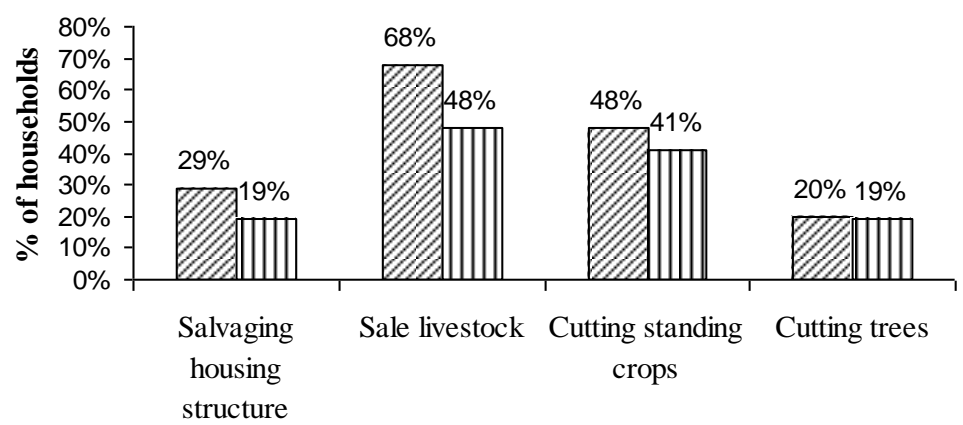

Techniques to loss reduction

Fig. 5. Loss reduction techniques of displacees during riverbank erosion

Use of movable housing materials

Displaces of both villages widely use the movable housing materials in constructing their houses on the char land. It is a purposive type of adaptation techniques (Elahi et al., 1991). Study shows that the housing materials were usually traditional in both villages. Housing structure was constructed of local roof materials, e.g., thatch, Sola (Jute Stick), CI sheet (tin made sheet) or corrugated iron sheet etc. and wall materials, e.g., mud-dough, thatch, bamboo, CI sheet etc. These materials are easily movable and less susceptible to the damage caused by riverbank erosion and have reusable and resalable value during and after erosion attack. Maximum number of people in two villages use CI sheet as their both roof and wall material. CI sheet is tin made sheet. This is widely used because this is very easy to move and could be used for many years rather than any other materials. Majority of the displacees (90\% in Degreer and $98 \%$ in Shushua char) used corrugated iron sheet (CI sheet) as roof material in constructing of their houses (Table 6) and rest of the displacees used thatch. In Shushua a large number of displacees $(48 \%)$ use CI sheet as wall material and others use jute stick and bamboo for this purpose. Interestingly, bamboo is mostly used as wall material in Degreer char followed by CI sheet and jute stick (Table 6).

Table 6. Coping techniques of displacees during riverbank

\begin{tabular}{|c|c|c|c|c|c|c|c|}
\hline \multicolumn{2}{|c|}{ Coping techniques } & \multicolumn{2}{|c|}{$\mathrm{DC}$} & \multicolumn{2}{|c|}{$\mathrm{SC}$} & \multicolumn{2}{|c|}{ Both chars } \\
\hline & & $\mathrm{HH}$ & $\%$ & $\mathrm{HH}$ & $\%$ & $\mathrm{HH}$ & $\%$ \\
\hline \multicolumn{8}{|c|}{ Shifting lives and properties } \\
\hline \multicolumn{2}{|c|}{ Family members } & 100 & 100 & 100 & 100 & 200 & 100 \\
\hline \multicolumn{2}{|c|}{ Tangible properties } & 64 & 64 & 76 & 76 & 140 & 70 \\
\hline \multirow{2}{*}{\multicolumn{2}{|c|}{ Livestock's }} & 90 & 90 & 78 & 78 & 168 & 84 \\
\hline & & \multicolumn{6}{|c|}{ Use of movable housing materials } \\
\hline \multirow{6}{*}{ Roof materials } & CI sheet & 90 & 90 & 98 & 98 & 188 & 94 \\
\hline & Thatch & 10 & 10 & 2 & 2 & 12 & 6 \\
\hline & Tile & 0 & 0 & 0 & 0 & 0 & 0 \\
\hline & RCC & 0 & 0 & 0 & 0 & 0 & 0 \\
\hline & Jute stick & 0 & 0 & 0 & 0 & 0 & 0 \\
\hline & Others & 0 & 0 & 0 & 0 & 0 & 0 \\
\hline \multirow{5}{*}{ Wall materials } & Bamboo & 41 & 41 & 12 & 12 & 53 & 26 \\
\hline & Mud-dough & 0 & 0 & 0 & 0 & 0 & 0 \\
\hline & Brick & 0 & 0 & 0 & 0 & 0 & 0 \\
\hline & Jute stick & 20 & 20 & 40 & 40 & 60 & 30 \\
\hline & CI sheet & 39 & 39 & 48 & 48 & 87 & 44 \\
\hline
\end{tabular}

Note: $\mathrm{DC}=$ Degreer char, $\mathrm{SC}=$ Shushua char 


\section{Investment pattern}

Investment pattern is quite different in two study villages during and after riverbank erosion. In Degreer char majority of the displacees invested their capital for purchasing livestock while in Shushua land lease which is locally known as Medi is the major investment option. Land lease is frequent in Shushua mainly for its poor economic condition. Displacees of both villages also invested in purchasing movable properties and land and few displacees of Shushua invested their own land. Distribution of different investment pattern to cope with riverbank erosion is presented in Fig. 6.

Stay in the place of shelter

After displacement, the displacees of char villages located in the Jamuna River moved to safer part like different riparian villages or in the other safe char

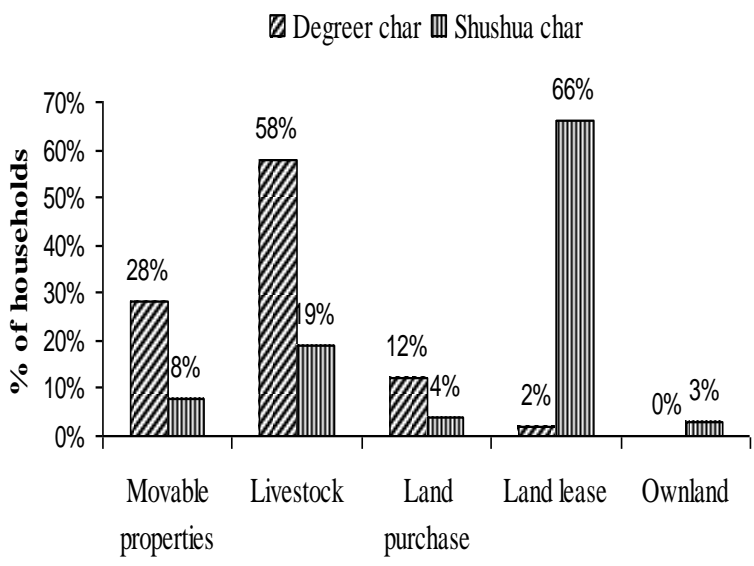

Investment pattern

Fig. 6. Investment pattern to cope with erosion attack

Drinking water use and sanitation situation

It is the inhuman condition that most of the displaces did not access to safe drinking water as the study villages had tube wells but washed away by the erosion. In the sheltered place displacees did not get sufficient safe drinking water in the neighbor's land or kin's land or in the embankment or in the nearby char. It is tough to get tube wells in the new char. Moreover the owners of such water sources allow displacees to fetch drinking water. It is accounted that 61\% Degreer and 39\% in Shushua char displaces had the safe drinking water availability after erosion attack. It was found that $58 \%$ in Degreer and $48 \%$ in Shushua char displacees had no access to latrine (Fig. 8). From the data exploration shows that only $7 \%$ displaces of Degreer char got hygienic latrine while $2 \%$ of Shushua char and rest of displaces got land. They take shelter on the embankment of the river, on neighbor's land, nearby char villages and under the shed of kin or neighbors. They were also supported by their kin or neighbors in having drinking water and sanitation facilities to some extent. Study found that majority of the displacees of both villages sheltered under their kin's shed $39 \%$ in Degreer and $39 \%$ in Shushua char) and on their neighbor's or relative's land $(15 \%$ in Degreer and $29 \%$ in Shushua char) and they are locally called Uthulis. It is noticeable that $24 \%$ of Degreer and $11 \%$ displacees of Shushua char were sheltered on the roads in the char land which is safe from the erosion attack (Fig. 7). They are suffered from the lack of drinking water, sanitation facilities and emergency health care services, and in addition to food crisis and lack of employment.

\section{\Degreer char $\square$ Shushua char}

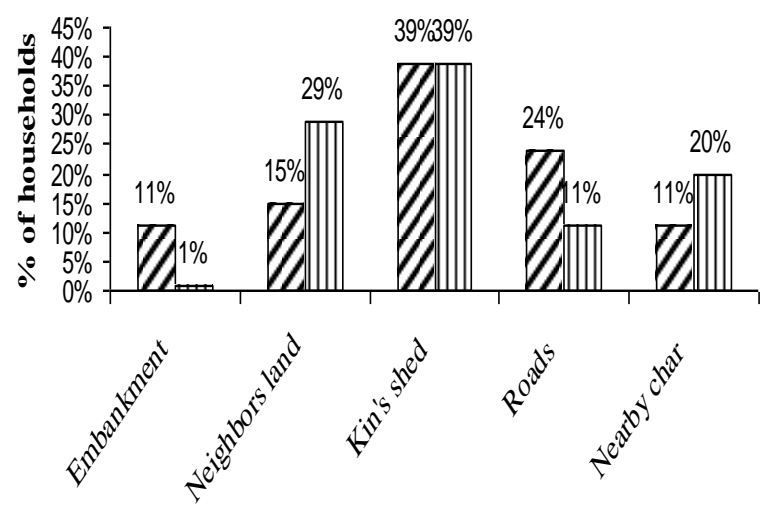

Places of temporary shelter

Fig. 7. Temporary shelter of displacees of riverbank erosion

unhygienic latrine (35\% in Degreer and 50\% in Shushua char).

Erosion and displaces ..

Table 7 demonstrates the frequency of shifting of household structure average in year and in the lifetime of the respondent household. Most of the displacees of both villages experience erosion attack in several times. All the settlements in the two study chars recorded displacement of dwelling units ranging from 1 to 15 times. Study explored that in Degreer char 63\% households experience 1-2 time erosion attack every year and $80 \%$ in Shushua char (Table 7). Most of the respondents in Degreer char experienced 7-9 times erosion attack (83\%) in their lifetime while only $13 \%$ in Shushua char. 
Q Degreer char $\mathbb{\square}$ Shushua char

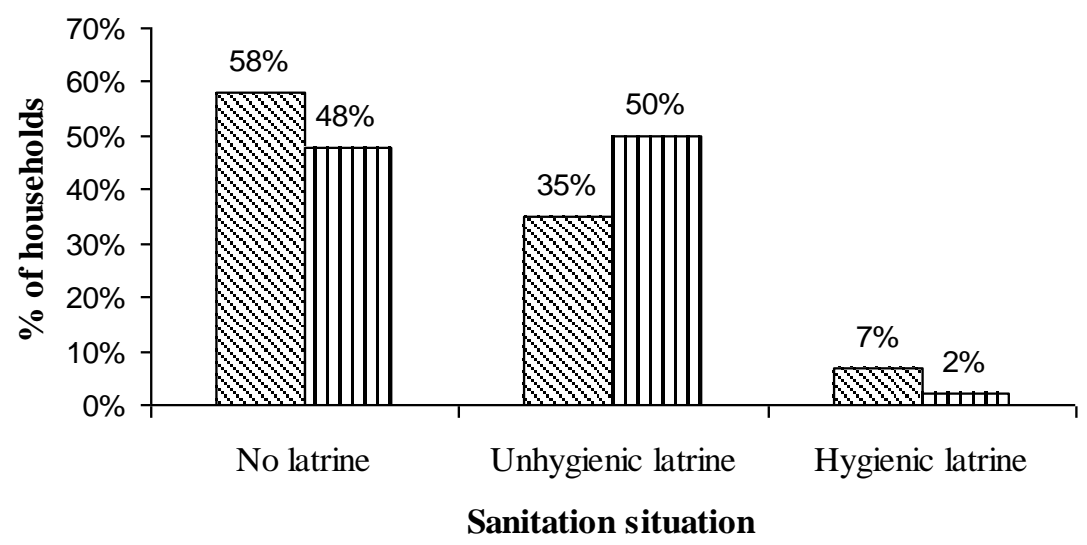

Fig. 8. Sanitation status of two chars during and immediately after erosion attack

Table 7. Experience displacement in a year and in a lifetime by the river erosion

\begin{tabular}{|l|c|c|c|c|}
\hline \multirow{2}{*}{ Displacement frequency } & \multicolumn{2}{|c|}{ No. of house holds } & \multicolumn{2}{|c|}{ Percentage (\%) } \\
\cline { 2 - 5 } & DC & SC & DC & SC \\
\hline Yearly & & & & 83 \\
\hline $1-2$ times & 63 & 80 & 36 & 20 \\
\hline 3-4 times & 36 & 20 & 1 & - \\
\hline 5-6 times & 1 & - & 100 & 100 \\
\hline Total & 100 & 100 & & \\
\hline Lifelong & & & & 43 \\
\hline $1-3$ times & - & 43 & - & 43 \\
\hline 4-6 times & 17 & 43 & 17 & 13 \\
\hline 7-9 times & 83 & 13 & 83 & 1 \\
\hline $10-$ above times & - & 1 & - & 100 \\
\hline Total Note: DC= Degreer char, SC= Shushua char & 100 & 100 & 100 & \\
\hline
\end{tabular}

Floods and Riverbank erosion in the deltaic valley is no small problems. This study finds that flooding and erosion have disastrous impacts on people's socioeconomic condition as well as on the environment The present study relates to two char villages in the middle of the country of Bangladesh, both adapting to flooding and erosion by means of a wide range of practices. In the study areas it is seen that the most of the houses is built on CI sheet, bamboo and thatch. People adopted multiple techniques in accepting loss, reducing loss, and in shifting their lives and properties due to flood and riverbank erosion. Finally, this study confirms that although flooding and river erosion in Bangladesh always generates socioeconomic and health related hazards and environmental and infrastructural damage, people's indigenous coping techniques can significantly reduce their vulnerability to disaster. ...

\section{Acknowledgement}

Sincere gratitude goes to the authorities of Arjuna and Gabsara union, Bhuapur, Tangail, Bangladesh for providing with valuable information's regarding the study. Thanks due to the local people who are living in the char and provided necessary information, helpful discussion, explanation and valuable suggestion during the field work of the study. Special thanks to the relevant personnel of BWDB for their cordial help and support to collect related literature and information's. 


\section{References}

Abrar C. R. and Azad, N. 2004. Coping with Displacement: riverbank Erosion in NorthWest Bangladesh, North Bengal Institute, and Refugee and Migratory Movements Research Unit (RMMRU), Dhaka: RDRS Bangladesh.

Adnan, S. 1991. Floods, people and environment: Institutional aspects of flood protection programmes in Bangladesh, Research and Advisory Services, Dhaka.

Blaikie, P.; T. Cannon, T. Davis, I. and Wisner, B. 1994. At Risk: Natural Hazards, People's Vulnerability, and Disasters, Routledge, London.

Elahi, K. M. 1991. Impacts of riverbank erosion and flood in Bangladesh: An introduction. Riverbank Erosion Impact Study, Jahangirnagar University, Dhaka, p.11-67.

Elahi, K. M.; Ahmed, K. S. and M. Mafizuddin, M. 1991. Riverbank Erosion, Flood and Population Displacement in Bangladesh. Jahangirnagar University, Dhaka: REIS.

Islam, M. Z. A. 2009. Indigenous Adaptation Strategies of the Riverbank Erosion Displacees in Bangladesh: A Study of Two Northwestern Riparian Villages, in $7^{\text {th }}$ Int. conf. on the human dimensions of global change, Bonn, Germany, p 3-11.

Kar, K. and Hossain, F. 2001. Mobility of the People of chars and Riverbanks of Bangladesh. A study of Gaibandha, DFID-B, Dhaka.

Lewis, J. 1999. Development in disaster-prone places: Studies of vulnerability, Intermediate Technology Publications, London.
Parker, D. J. and Tunstall, S. M. 1991. Managing flood warning system: The United Kingdom experience, in Annual Conf. of the Association of State Floodplain managers, Denver, Co., United States.

Penning-Rowsell, E. C. and M. Fordham. 1994. Floods across Europe: Flood Hazard Assessment, Modeling and Management, Middlesex University Press, London, p. 3268.

Roy, M. K.; Syed, S. U. I. and Azim, A. 2007. Settlement of a char land Community: A Study on Social Crisis and Coping Pattern, in seminar organized Bangladesh Economic Association, Dhaka, Bangladesh.

Tod, I. 2007. Assessment of the effectiveness of the homestead raising and mound protection works implemented by the Shouhardo program, CARE Bangladesh.

Wescoat, J. L. and Jacobs, J. W. 1993. The Evolution of Flood Hazards Programs in Asia: The Current Situation, University of Colorado, Boulder, Co.

Zaman, M. Q. 1989. Patron-based, Non-kin Segmentary Model-The Dynamics of Political Alliance in Riverine Bangladesh, in Annual Meetings of the American Anthropological Association, Washington, D.C., USA, p. 30.

Zaman, M. Q. and R. E. Wiest. 1985. Local Level Socio-economic and Political Dynamics of Accretional and Depositional Land Erosion and Flood Hazards in Bangladesh, Dhaka. Jahangirnagar University, p 16. 